\title{
PENGEMBANGAN BAHAN AJAR MATEMATIKA BERBASIS INTEGRASI- INTERKONEKSI UNTUK MEMFASILITASI PENALARAN DAN PEMECAHAN MASALAH
}

\author{
Mulin Nu'man \\ Program Studi Pendidikan Matematika UIN Sunan Kalijaga Yogyakarta \\ mulin_numan@yahoo.com
}

\begin{abstract}
This research aims to produce and see the effectiveness of interconnection-based mathematicsbased teaching materials to facilitate the reasoning and problem solving skills of high school students. The method used is research model development Borg \& Gall with three phases: an introduction that includes literature review and analysis of student characteristics, stage of development which include determining the basic competencies and indicators, the analysis of the materials, writing materials, and instruments, and the stage of validation includes expert validation, revision I, small group trial, analysis of the trial results, revision II, and packaging the final product. The research result is drafting a set of mathematics teaching materials based integration-interconnection effective to facilitate of reasoning and problem-solving abilities of high school students worthy with the results of assessment of Very Good is 157.5 of the maximum score 172 or persentage $91.2 \%$ and posttest result of average mathematical reasoning 77.21 and average problem solving ability 76.01. In addition of the test is found that teaching materials can be used well in learning with positive impact.
\end{abstract}

Keywords:mathematics teaching materials, interconnect integration, reasoning, problem solving

\section{PENDAHULUAN}

Dewasa ini, indeks persaingan global diukur menggunakan GCI (Global Competitive Index). Pada tahun 2011, indeks persaingan global Indonesia masih cukup baik, yakni peringkat ke-44 dari 133 negara. Sedangkan pada tahun 2012, indeks persaingan global Indonesia mulai menurun menjadi peringkat 46 dan terus menurun pada tahun 2013 menjadi peringkat 50. Makin menurunnya indeks persaingan global Indonesia salah satunya dikarenakan rendahnya kesiapan teknologi dan inovasi (Ace Suryadi, 2014:20). Jika rendahnya kesiapan teknologi dan inovasi di Indonesia tidak segera ditanggulangi, maka tidak mengherankan jika indeks persaingan global Indonesia akan semakin menurun. Peningkatan indeks persaingan global Indonesia membutuhkan pembangunan manusia yang lebih giat lagi. Peningkatan kualitas sumber daya manusia diantaranya dapat dilakukan dengan memperbaiki pendidikannya (Ace Suryadi, 2011:24).

Salah satu perbaikan pendidikan yang harus dilakukan adalah dengan meningkatkan efektivitas pembelajaran matematika. Matematika perlu diberikan kepada semua siswa baik dari jenjang sekolah dasar, sekolah menengah, bahkan sekolah tinggi bertujuan dintaranya untuk memberikan bekal siswa dengan kemampuan berpikir secara logis, analitis, sistematis, kritis, kreatif serta kemampuan bekerja sama.Kemampuankemampuan tersebut diperlukan siswa untuk bertahan dalam kehidupan yang semakin kompetitif. Lebih lanjut tujuan pembelajaran matematika kepada siswa berdasarkan Peraturan Menteri Pendidikan Nasional Nomor 22 Tahun 2006 dalam Ibrahim dan Suparni (2008:36-37), antara lain:

1. Memahami konsep matematika, menjelaskan keterkaitan antarkonsep dan mengaplikasikan konsep secara luwes, akurat, efisien serta tepat dalam pemecahan masalah;

2. Menggunakan penalaran pada pola dan sifat, melakukan manipulasi matematika dalam membuat generalisasi, menyusun bukti, atau menjelaskan gagasan dan pernyataan dalam matematika;

3. Memecahkan masalah yang meliputi kemampuan memahami masalah, merancang model matematika, 
Pengembangan Bahan Ajar Matematika Berbasis Integrasi-Interkoneksi untuk Memfasilitasi Kemampuan Penalaran dan Pemecahan Masalah Siswa

Mulin Nu'man

menyelesaikan model dan menafsirkan penyelesaian yang siswa dapatkan;

4. Mengkomunikasikan gagasan dengan simbol, tabel, diagram, atau media lain untuk memperjelas keadaan atau masalah;

5. Memiliki sikap menghargai kegunaan matematika dalam kehidupan, yakni memiliki rasa ingin tahu, perhatian, dan minat dalam mempelajari matematika, serta sikap ulet dan percaya diri dalam pemecahan masalah.

Berdasarkan tujuan pembelajaran matematika di atas, kemampuan penalaran dan pemecahan masalah merupakan kemampuan yang diharapkan terwujud melalui pembelajaran matematika di sekolah, baik sekolah dasar maupun sekolah menengah. Seorang anak dapat dikatakan memiliki kecakapan dalam matematika jika penguasaan konsep matematika yang baik, penalaran yang logis, serta disposisi yang positif yakni sikap mempercayai bahwa matematika bermanfaat dalam kehidupannya. Didukung oleh Ball, Lewis \& Thamel (dalam Bambang Riyanto dan Rusdy A. Siroj, 2011:3) bahwa "mathematical reasoning is the foundation for the construction of mathematical knowledge". Hal ini menegaskan bahwa kemampuan penalaran merupakan pondasi untuk kokohnya pengetahuan matematika seseorang. Selain itu, menurut Jhonson dan Rising (dalam Bambang Riyanto dan Rusdy A. Siroj, 2011:3) bahwa "mathematics is a creation of the human mind, concerned primarily with idea processes and human reasoning", ungkapan Jhonson dan Rising ini mengungkapkan bahwa matematika merupakan hasil pemikiran manusia yang erat kaitannya dengan proses-proses kehidupan, pencetusan ide-ide serta penalaran. Karena kemampuan penalaran dan matematika merupakan suatu kesatuan yang saling berkaitan, maka peningkatan kemampuan penalaran dalam pembelajaran matematika adalah sesuatu yang harus diusahakan.

Rendahnya kemampuan penalaran siswa dapat dilihat dari skor PISA (Programme for International Student Assessment) dan TIMSS (Trends In International Mathematics and Science Study) yang merupakan salah satu tolok ukur kemampuan penalaran siswa (Ramadhan,
2013:21). Skor perolehan survei PISA dan TIMSS dapat dilihat dalam tabel berikut ini:

Tabel 1. Peringkat Prestasi Matematika Siswa Indonesia Dibanding Negara Partisipan Berdasarkan Hasil Survei TIMSS

\begin{tabular}{|c|c|c|c|c|}
\hline $\begin{array}{l}\text { 壱 } \\
\stackrel{\Xi}{\oplus}\end{array}$ & 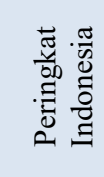 & 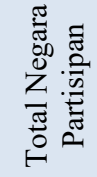 & 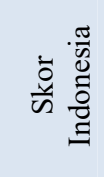 & 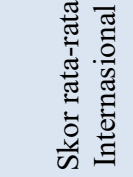 \\
\hline 1999 & 34 & 38 & 403 & 487 \\
\hline 2003 & 35 & 46 & 411 & 467 \\
\hline 2007 & 36 & 49 & 397 & 500 \\
\hline 2011 & 38 & 42 & 386 & 500 \\
\hline 2015 & 45 & 50 & 397 & 475 \\
\hline
\end{tabular}

\section{Sumber:}

http://litbang.kemdikbud.go.id/index.php/timss (1999-2007)

http://timssandpirls.bc.edu/data-release-

2011/pdf/Overview-TIMSS-and-PIRLS-2011-

Achievement.pdf (2011)

Tabel 2. Peringkat Prestasi Matematika Siswa Indonesia Dibanding Negara Partisipan Berdasarkan Hasil Survei PISA

\begin{tabular}{|c|c|c|c|c|}
\hline 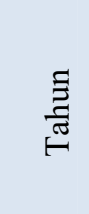 & 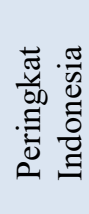 & 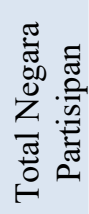 & 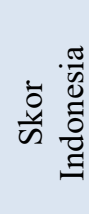 & 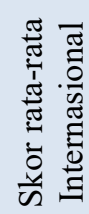 \\
\hline 2000 & 39 & 41 & 367 & 500 \\
\hline 2003 & 38 & 40 & 360 & 500 \\
\hline 2006 & 50 & 57 & 391 & 500 \\
\hline 2009 & 57 & 63 & 371 & 500 \\
\hline 2012 & 64 & 65 & 375 & 500 \\
\hline 2015 & 69 & 76 & 386 & 490 \\
\hline
\end{tabular}

\section{Sumber:}

http://litbang.kemdikbud.go.id/index.php/survei -internasional-pisa (2000-2006)

https://www.oecd.org/pisa/pisaproducts/466197 03.pdf (2009)

https://www.oecd.org/pisa/keyfindings/pisa2012-results-overview.pdf (2012)

Berdasarkan skor PISA serta skor TIMSS di atas, dapat disimpulkan kemampuan penalaran siswa di Indonesia masih sangat rendah. 
Proses pemecahan masalah matematik merupakan salah satu kemampuan dasar matematik yang harus dikuasai siswa sekolah menengah. Pentingnya pemilikan kemampuan tersebut tercermin dari pernyataan Branca (dalam Hendriana \& Soemarmo, 2014: 23) bahwa pemecahan masalah matematik merupakan salah satu tujuan penting dalam pembelajaran matematika bahkan proses pemecahan masalah matematik merupakan jantungnya matematika. Sejalan dengan pendapat Branca, Cooney (dalam Hendriana \& Soemarmo, 2014: 23) mengemukakan bahwa pemilikan kemampuan pemecahan masalah membantu siswa berpikir analitik dalam mengambil keputusan dalam kehidupan seharihari dan membantu meningkatkan kemampuan berpikir kritis dalam menghadapi situasi baru.

Bahan ajar memiliki peran penting dalam kegiatan pembelajaran, Greene dan Petty dalam Komalasari (2010:43) menyebutkan di antaranya:

1. Menyajikan pokok masalah yang kaya, mudah dibaca dan bervariasi sesuai dengan kebutuhan siswa

2. Menyediakan sumber belajar yang sistematis mengenai keterampilan ekspresional dan melingkupi pokok permasalahan komunikasi.

3. Menyajikan fiksasi awal yang perlu sebagai penunjang bagi latihan dan tugas.

4. Menyajikan bahan evaluasi yang sesuai dan tepat guna.

Bahan ajar yang beredar di pasaran berorientasi pada bahan pelajaran yang formal dan diambil dari disiplin ilmu pendukungnya, namun kurang memperhatikan bahan pelajaran yang diambil dari lingkungan tempat tinggal siswa sehingga hubungan konsep yang dipelajari oleh siswa melalui bahan ajar tersebut kurang berhubungan dengan kehidupan seharihari siswa (Komalasari, 2010:43).

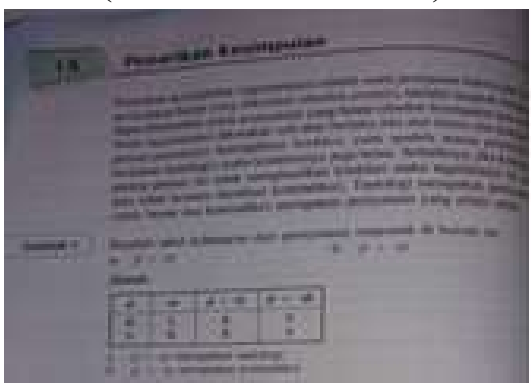

Gambar 1. Kutipan Bahan Ajar
Berdasarkan kutipan bahan ajar di atas, materi disajikan secara langsung tanpa mengajak siswa untuk menemukan kembali konsep yang dipelajarinya. Dengan memberikan konsep secara langsung pada siswa, pengetahuan yang didapat siswa menjadi kurang bermakna karena tidak ada proses asimilasi konsep baru dengan konsep yang telah didapatkan siswa (Komalasari, 2010: 21).

Keraf dalam Fadjar Shadiq (2003:4) mengemukakan bahwa penalaran merupakan proses berpikir yang berusaha menghubungkan fakta-fakta yang telah diketahui siswa menuju suatu kesimpulan. Pembelajaran yang menyajikan fakta-fakta dalam kehidupan seharihari siswa memungkinkan siswa dapat menghubungkan fakta-fakta tersebut sehingga diharapkan kemampuan penalaran siswa akan meningkat. Salah satu pembelajaran yang menghubungkan konsep yang akan dipelajari siswa dengan kehidupan sehari-harinya adalah pembelajaran kontekstual (Komalasari, 2010:6).

Pembelajaran kontekstual dapat menunjukkan kepada siswa keterkaitan antara matematika dengan dunia nyata, serta kegunaan matematika bagi kehidupan manusia dan memberi pengertian kepada siswa bahwa matematika merupakan suatu ilmu yang tumbuh dan berkembang dari kehidupan manusia (Wardhani, 2002:5-8).

Komalasari karakteristik-karakteristik pembelajaran kontekstual (2010:13-15) sebagai berikut:

1) Keterkaitan (Relating)

2) Pengalaman langsung (Experiencing)

3) Aplikasi (Applying)

4) Kerja sama (Cooperating)

5) Pengaturan Diri (Self-regulating)

6) Penilaian Autentik (Authentic Assessment)

Integrasi-interkoneksi merupakan upaya untuk mempertemukan antara ilmu agama (Islam) dengan ilmu-ilmu umum yang meliputi sosial humaniora serta sains dan teknologi yang termasuk di dalamnya adalah matematika (Tim Penyusun POKJA akademik UIN Sunan Kalijaga dalam Mussafi, 2014:1). Dalam implementasinya, integrasi-interkoneksi berusaha menghubungkan ilmu-ilmu agama dengan ilmu sosial humaniora, ilmu-ilmu agama dengan sains dan teknologi, maupun 
menghubungkan ilmu sosial humaniora dengan sains dan teknologi. Diantara ketiga macam implementasi tersebut, yang paling utama adalah menghubungkan ilmu-ilmu umum (sosial humaniora dengan sains dan teknologi) dengan ilmu-ilmu agama.

Dalam ranah integrasi-interkoneksi, upaya untuk menghubungkan ilmu agama dan ilmu umum dapat dikategorikan dalam ranah filosofi, metodologi, materi maupun strategi (Mussafi, 2015:4). Dalam ranah materi, integrasi-interkoneksi mencoba menghubungkan nilai-nilai kebenaran universal dengan nilai-nilai keislaman khususnya dalam suatu disiplin ilmu pengetahuan tertentu, salah satunya adalah matematika. Nilai-nilai kebenaran universal dalam matematika sejatinya dapat dihubungkan dengan nilai-nilai keislaman, hanya saja belum banyak guru yang mencoba mengintegrasi-interkoneksikan matematika dengan nilai-nilai keislaman.

Menitik dari penelaahan di atas, maka peneliti mengajukan tema penelitian "Pengembangan Bahan Ajar Matematika Berbasis Integrasi-Interkoneksi untuk Memfasilitasi Kemampuan Penalaran dan Pemecahan Masalah Siswa". Dengan bahan ajar yang akan dikembangkan tersebut, diharapkan dapat meningkatkan kemampuan penalaran dan pemecahan masalah siswa dan dapat digunakan sebagai salah satu alternatif sumber belajar siswa.

Produk yang dihasilkan adalah bahan ajar matematika berbasis integrasi-interkoneksi dan kontekstual untuk memfasilitasi kemampuan penalaran dan kemampuan pemecahan masalah siswa. Spesifikasi bahan ajar yang dihasilkan adalah:

1. Berbentuk bahan ajar cetak dengan tiga pokok bahasan, yaitu logika matematika, geometri ruang, dan trigonometri

2. Dalam setiap babnya disajikan pojok alQuran, materi pokok, masalah, rangkaian aktivitas siswa, dan soal latihan.

3. Masalah yang dikembangkan adalah masalah kontekstual dan mengarah pada penalaran dan pemecahan masalah.

4. Untuk memberi motivasi, diberikan biografi matematikawan yang sukses dalam mengembangkan ilmu matematika.
5. Dicetak dengan huruf berukuran 12pts dan dicetak berwarna.

\section{METODE PENELITIAN}

\section{A. Metode Penelitian}

Penelitian ini merupakan penelitian pengembangan (Research and Development). Penelitian pengembangan ini menggunakan model pengembangan prosedural diadaptasi dari Borg \& Gall dengan tiga tahap yaitu tahap pendahuluan, tahap pengembangan, dan tahap validasi (Sugiono: 2010).

Prosedur pengembangan merupakan penjelasan dari model pengembangan yang telah ditetapkan. Langkah-langkah yang ditempuh dalam prosedur pengembangan yaitu:

\section{Pendahuluan}

a. Studi pustaka.

b. Analisis kebutuhan dan karakteristik siswa.

c. Merencanakan dan memilih jenis media pembelajaran yang akan digunakan.

\section{Pengembangan}

a. Menentukan standar kompetensi, kompetensi dasar, indikator, dan materi pokok yang akan disajikan.

b. Menyusun bahan ajarmatematika berbasis integrasi-interkoneksi dan kontekstual untuk siswa SMA/MA.

c. Pembuatan instrumen penelitian dengan validasi ahli sebagai alat ukur kualitas bahan ajar, dan pedoman wawancara, dan soal.

\section{Validasi}

Dalam penelitian ini, validasi dilakukan sampai pada tahap uji coba terbatas.Hal ini dikarenakan keterbatasan waktu.
a. Validasi oleh Ahli
b. Revisi I
c. Uji Kelompok Kecil
d. Analisis Hasil Evaluasi Kelompok Kecil
e. Revisi II
f. Distribusi Produk Akhir

\section{B. Data dan Sumber Data}

Data dalam penelitian ini meliputi:

1. Data kemampuan penalaran matematis dan kemampuan pemecahan masalah. 
Halaman $31-42$

2. Kualitas bahan ajar

Data kualitas bahan ajar digunakan untuk mengetahui kualitas bahan ajar dari segi ketepatan materi, masalah yang disajikan, dan keseluruhan bentuk bahan ajar.Data ini diambil dari dua orang validator ahli.

3. Ujicoba bahan ajar

Ujicoba bahan ajar matematika berbasis integrasi-interkoneksi dan kontekstual untuk siswa SMA/MA di sekolah, sehingga sumber datanya adalah siswa SMA N 1 Sewon Bantul, MA Ali Maksum Bantul, dan MAN Lab UIN Yogyakarta.

\section{Instrumen dan Pengumpulan Data}

Instrumen dalam penelitian ini adalah pedoman wawancara dan lembar penilaian. Sedangkan pengumpulan data adalah wawancara dan penilaian kualitas bahan ajar.

\section{Analisis Data}

Data yang diperoleh dalam penelitian ini akan dianalisis melalui tahapan sebagai berikut:

1. Data kemampuan penalaran matematis dan kemampuan pemecahan masalah dianalisis dengan statistik deskriptif.

2. Data kualitatif yang diperoleh dari lembar penilaian dan pedoman wawancara dianalisis secara kualitatif.

3. Data yang diperoleh melalui lembar penilaian validator yang berupa huruf diubah menjadi nilai kualitatif dengan langkah-langkah sebagai berikut:

a. Jenis data yang diambil berupa data kualitatif dengan menggunakan skala Likert kemudian diubah menjadi kuantitatif dengan ketentuan yang dapat dilihat dalam Tabel 3.1 sebagai berikut:

Tabel 3. Aturan Pemberian Skala

\begin{tabular}{|l|l|}
\hline \multicolumn{1}{|c|}{ Keterangan } & Skor \\
\hline SB (sangat baik) & 4 \\
\hline B (baik) & 3 \\
\hline K (kurang) & 2 \\
\hline SK (sangat kurang) & 1 \\
\hline
\end{tabular}

b. Setelah data terkumpul, kemudian menghitung skor rata-rata.

c. Mengubah nilai tiap aspek kriteria dalam masing-masing komponen bahan ajar matematika menjadi nilai kualitatif sesuai dengan kriteria kategori penilaian ideal dengan ketentuan dalam Tabel 4 berikut (Sudijono, 1987: 161):

Tabel 4. Kriteria Kategori Penilaian Ideal

\begin{tabular}{|l|c|c|}
\hline No & $\begin{array}{c}\text { Rentang skor } \\
\text { kuantitatif }(\boldsymbol{x}) \boldsymbol{\%}\end{array}$ & $\begin{array}{c}\text { Kategori } \\
\text { Kualitatif }\end{array}$ \\
\hline 1 & $x>80$ & Sangat Baik \\
\hline 2 & $70<x \leq 80$ & Baik \\
\hline 3 & $60<x \leq 70$ & Cukup \\
\hline 4 & $50<x \leq 60$ & Kurang \\
\hline 5 & $x \leq 50$ & Sangat Kurang \\
\hline
\end{tabular}

Menentukan nilai keseluruhan bahan ajar matematika dengan menghitung skor ratarata seluruh materi pokok.Kemudian diubah menjadi nilai kualitatif sesuai dengan kriteria kategori penilaian ideal pada bahan ajar.

\section{HASIL DAN PEMBAHASAN}

\section{A. Hasil Penelitian}

Penelitian pengembangan yang dilakukan dengan tiga tahap, yaitu: 1) tahap pendahuluan, 2) tahap pengembangan, dan 3 tahap validasi. Ketiga tahap tersebut dirinci sebagai berikut:

1. Tahap Pendahuluan

a) Studi pustaka, yaitu mengkaji teoriteori dan hasil penelitian yang relevan dengan penelitian dan pengembangan yang akan dilakukan.

b) Menganalisis karakteristik siswa. Analisis dilakukan terhadap siswa melalui pengamatan karakteristik siswa dalam pembelajaran di kelas. Analisis karakteristik dilakukan di tiga sekolah, yaitu SMAN 1 Sewon, SMA Ali Maksum, dan MAN Lab UIN Yogyakarta

Tabel 5. Hasil Analisis Karakteristik Siswa

\begin{tabular}{|c|l|}
\hline Karakteristik Siswa & \multicolumn{2}{|c|}{$\begin{array}{c}\text { Penyesuaian yang } \\
\text { dilakukan }\end{array}$} \\
\hline $\begin{array}{l}\text { Nilai ulangan harian } \\
\text { siswa rendah, hal ini }\end{array}$ & $\begin{array}{l}\text { Penyusunan bahan } \\
\text { ajar }\end{array}$ matematika \\
dapat dipengaruhi oleh & yang diharapkan \\
\hline
\end{tabular}


Pengembangan Bahan Ajar Matematika Berbasis Integrasi-Interkoneksi untuk Memfasilitasi Kemampuan Penalaran dan Pemecahan Masalah Siswa

Mulin Nu'man

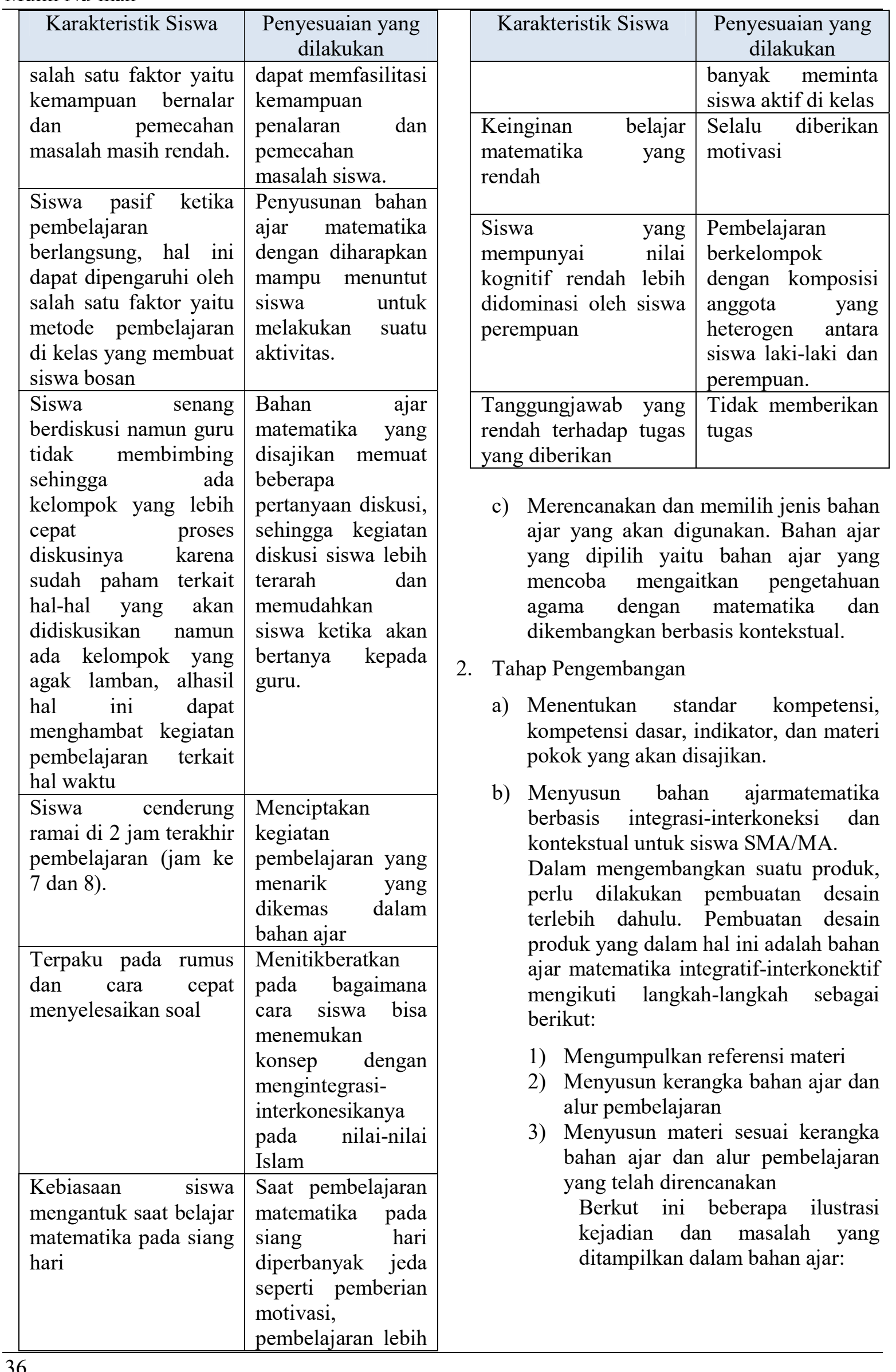




\section{Ilustrasi Kejadian 1}

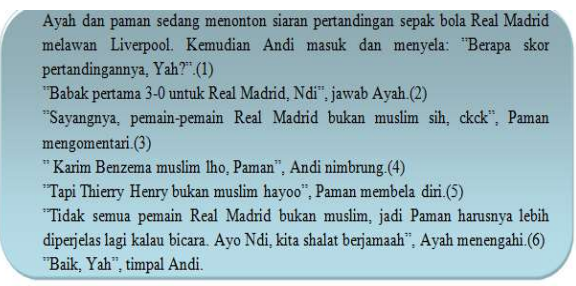

Gambar 2. Ilustrasi Kejadian 1

Ilustrasi kejadian 1 diproyeksikan untuk mengarahkan siswa memahami materi pernyataan dan kalimat terbuka. Berdasarkan ilustrasi kejadian tersebut, siswa diberi petunjuk kalimat mana yang termasuk kalimat terbuka, serta mana yang merupakan pernyataan, kemudian siswa diminta untuk mengidentifikasi alasannya.

Pojok al-Quran

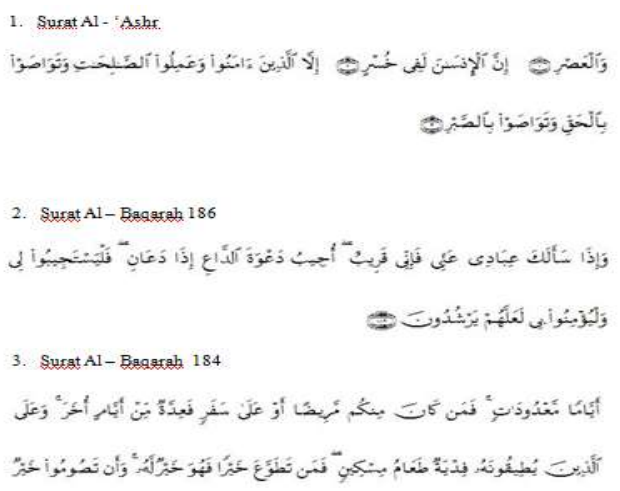

Gambar 3. Pojok al-Quran

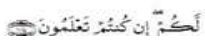

Pojok al-Quran merupakan pernakpernik bahan ajar matematika integratif-interkonektif yang mengaitkan nilai-nilai kebenaran kalimat majemuk yang dipelajari siswa dalam matematika dengan nilai-nilai kebenaran keislaman, dalam beberapa surat dalam alQuran, sehingga siswa diharapkan dapat lebih menghayati matematika dan kehidupan kesehariannya, terutama kehidupan keagamaannya.

4) Melengkapi unsur-unsur bahan ajar sesuai kerangka

Penampilan dalam bahan ajar adalah sesuatu yang penting untuk diperhatikan. Agar terlihat lebih atraktif, ilustrasi kejadian maupun masalah yang disajikan dalam bahan ajar perlu dilengkapi dengan unsur-unsur pendukung, seperti gambar ilustrasi.

5) Merancang tampilan/ layout bahan ajar

Desain cover dan layout yang dirancang disesuaikan dengan kuesioner mengenai bahan ajar yang diinginkan oleh subjek penelitian. Tampilan cover dan layout berwarna biru dengan layout tema alam. Desain cover bahan ajar dapat dilihat pada gambar di bawah ini.

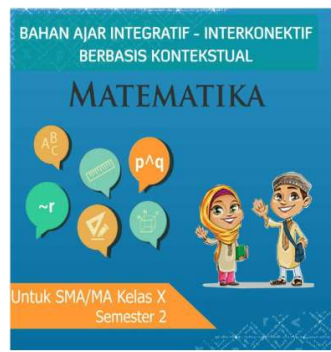

Gambar 4. Cover

c) Pembuatan instrumen penelitian dengan validasi ahli sebagai alat ukur kualitas bahan ajar, dan pedoman wawancara, dan soalkemampuan penalaran dan pemecahan masalah siswa.

\section{Tahap Validasi}

Tahap selanjutnya adalah tahap validasi. Pada tahap validasi ini, peneliti melakukan 1) Validasi oleh Ahli, 2) Revisi I, 3) Uji Kelompok Kecil, 4) Analisis Hasil Evaluasi Kelompok Kecil, 5) Revisi II, dan 6) Distribusi Produk Akhir.

1) Validasi oleh Ahli

Validasi Ahli dilakukan untuk menjamin bahan ajar yang dihasilkan mempunyai kualitas yang baik dan bisa dipertanggungjawabkan, baik secara konseptual maupun secara tata tulis. Peneliti melibatkan dua orang ahli yang memahami tentang konsep matematika, pembelajaran matematika, dan integrasiinterkoneksi, yaitu Dr. Ibrahim, M.Pd dan Sintha Sih Dewanti, M.Pd.Si. Proses validasi menggunakan lembar penilaian yang dikembangkan oleh peneliti. 
Beberapa saran dari validator yaitu:

a) Perlu ditambahkan sejarah penting untuk subbab logika matematika dan geometri.

b) Variasi bentuk soal pada latihan sebaiknya dikombinasikan.

c) Nilai-nilai keislaman perlu ditambahkan lagi.

d) Beberapa struktur kalimat masih kurang tepat.

e) Layout diperbaiki lagi.

f) Beberapa istilah dan definisi perlu disepakati dan konsisten.

\section{2) Revisi I}

Revisi I dilakukan berdasarkan catatan pada bahan ajar dan saran tertulis dari validator. Beberapa revisi yang dilakukan adalah:

a) Memperbaiki lay out agar enak dilihat dan tidak menyulitkan siswa membaca teks.

b) Mendefinisikan ulang beberapa konsep dan istilah serta konsisten dalam penggunaan konsep dan istilah tersebut.

c) Menambahkan nilai-nilai islam dalam materi.

d) Menambah variasi soal latihan.

e) Memperbaiki tata bahasa dan penulisan.

Setelah proses validasi dan revisi, validator melakukan penilaian kelayakan bahan ajar. Hasil penilaian kelayakan adalah sebagai berikut:

Tabel 6. Hasil Penilaian Bahan Ajar

\begin{tabular}{|c|c|c|c|}
\hline \multirow{2}{*}{ No } & \multirow{2}{*}{ Hasil } & \multicolumn{2}{|c|}{ Nilai } \\
\hline & & Validator 1 & Validator 2 \\
\hline & Jumlah & 155 & 160 \\
\hline & Rata-rata & \multicolumn{2}{|c|}{157,5} \\
\hline & $\begin{array}{l}\text { Skor } \\
\text { maksimal }\end{array}$ & \multicolumn{2}{|c|}{172} \\
\hline & Persentase & \multicolumn{2}{|c|}{$91,2 \%$} \\
\hline & Kategori & \multicolumn{2}{|c|}{ Sangat Baik } \\
\hline
\end{tabular}

Dengan kategori sangat baik, bahan ajar dinyatakan layak digunakan. Selanjutnya bahan ajar akan diujicobakan pada pembelajaran.

3) Uji Kelompok Kecil

Uji coba dilakukan pada kelompok kecil (satu kelas) dan hanya pada materi geometri. Uji coba dilakukan selama 2 pertemuan dengan 6 JPL. Setelah ujicoba dilakukan posttest.

4) Analisis Hasil Evaluasi Kelompok Kecil

Hasil prostest diperoleh data sebagai berikut, rata-rata kemampuan penalaran adalah 77.21 dan rata-rata kemampuan pemecahan masalah adatal 76.01.

Selama proses pembelajaran dari pertemuan I dan II siswa sudah mengikuti instruksi guru dengan baik hanya saja masih dijumpai beberapa siswa yang masih kurang tepat menjawab suatu pertanyaan, khususnya pada bagian mengilustrasikan. Walaupun siswa belum tepat dalam mengilustrasikan namun kebanyakan jawaban perhitungan siswa sudah tepat. Diperoleh temuan dan dampak dari penggunaan bahan ajar matematika berupa:

1) Siswa awalnya belum percaya diri ketika diminta berargumentasi tentang suatu pengertian dan lebih percaya diri ketika menjawab suatu pertanyaan dengan jawaban pasti, namun setelah mencoba pada submateri pertama siswa sudah mulai percaya diri dengan argumentasinya.

2) Lemahnya kemampuan siswa ketika mengilustrasikan dari bentuk tiga dimensi ke dalam bentuk dua dimensi menjadi PR bagi guru.

3) Bagian hipotesis pada bahan ajar tidak tertulis kata "hipotesis" sehingga menyulitkan guru ketika meminta siswa untuk menyelesaikan bagian itu.

4) Materi prasyarat (rumus dasar perbandingan Trigonometri) yang sebelumnya oleh guru diandaikan siswa sudah hapal ternyata masih ada beberapa siswa yang lupa. Guru dalam hal ini menjelaskan di papan tulis, akan lebih baik jika tertulis juga dalam bahan ajar, walaupun tidak semua minimal salah satu misal cosinus agar dapat dijadikan sebagai batu loncatan untuk mengingat 2 rumus yang lain.

5) Siswa belum mengetahui cara mencari besar sudut jika diketahui nilai perbandingan sudutnya, hal ini karena bahasan materi Trigonometri pada pembelajaran sebelumnya hanya membahas sampai sudut berelasi. 
Halaman $31-42$

6) Bahan ajar matematika menuntun siswa langkah demi langkah, sehingga memudahkan siswa untuk menyelesaikan suatu permasalahan khususnya pada materi Geometri dimana kita tahu bahwa dalam materi Geometri tidak ada konsep khusus yang dapat dijadikan tanda ketika menghadapi soal seperti ini dapat dikerjakan dengan konsep ini.

Tabel 7. Dampak yang Dialami Siswa A, B, dan C

\begin{tabular}{|c|c|c|}
\hline Siswa & Pertemuan I & Pertemuan II \\
\hline \multirow[t]{3}{*}{ A } & $\begin{array}{lr}\text { Belum } & \text { bisa } \\
\text { mengajukan } & \\
\text { argumentasi } & \text { nilai } \\
\text { kebenaran } & \text { dan } \\
\text { negasi. } & \end{array}$ & $\begin{array}{lr}\text { Sudah } & \text { bisa } \\
\text { mengajukan } & \\
\text { argumentasi } & \\
\text { tentang } & \text { nilai } \\
\text { kebenaran } & \text { dan } \\
\text { negasi. } & \end{array}$ \\
\hline & $\begin{array}{l}\text { Belum bisa } \\
\text { membuat ilustrasi } \\
\text { tentang } \\
\text { pernyataan } \\
\text { kuantor. }\end{array}$ & $\begin{array}{l}\text { Sudah bisa } \\
\text { mengilustrasikan } \\
\text { pernyataan } \\
\text { kuantor. }\end{array}$ \\
\hline & $\begin{array}{l}\text { Belum tepat } \\
\text { mengilustrasikan } \\
\text { pertanyaan } \\
\text { diskusi } 2 \text { nomor } \\
3 \text {. }\end{array}$ & $\begin{array}{l}\text { Sudah tepat } \\
\text { mengilustrasikan } \\
\text { pertanyaan } \\
\text { diskusi } 3 \text { nomor } 2 \\
\text { dengan } \\
\text { karakteristik soal } \\
\text { mirip dengan } \\
\text { pertanyaan } \\
\text { diskusi } 2 \text { nomor } \\
3 \text {. }\end{array}$ \\
\hline \multirow[t]{2}{*}{ B } & $\begin{array}{l}\text { Jawaban siswa B } \\
\text { sudah mendekati } \\
\text { tepat hanya saja } \\
\text { belum spesifik } \\
\text { ketika menjawab } \\
\text { pertanyaan } \\
\text { diskusi } 1 \text { nomor } \\
1 \text {, kemudian } \\
\text { setelah siswa A } \\
\text { menyampaikan } \\
\text { gagasannya, } \\
\text { jawaban siswa B } \\
\text { menjadi tepat. }\end{array}$ & $\begin{array}{l}\text { Membantu } \\
\text { memahamkan } \\
\text { teman } \\
\text { sekelompoknya } \\
\text { yang kesulitan } \\
\text { memahami } \\
\text { pertanyaan } \\
\text { diskusi 3. Hanya } \\
\text { saja untuk } \\
\text { submateri sudut, } \\
\text { siswa B belum } \\
\text { memahami cara } \\
\text { membuktikan } \\
\text { suatu pengambilan } \\
\text { kesimpulan } \\
\text { adalah tautologi. }\end{array}$ \\
\hline & $\begin{array}{l}\text { Belum bisa } \\
\text { menyelesaikan }\end{array}$ & $\begin{array}{l}\text { Sudah } \\
\text { menyelesaikan }\end{array}$ \\
\hline
\end{tabular}

\begin{tabular}{|c|c|c|}
\hline$\overline{\text { Siswa }}$ & Pertemuan I & Pertemuan II \\
\hline & $\begin{array}{l}\text { masalah tentang } \\
\text { negasi pernyataan } \\
\text { berkuantor. }\end{array}$ & $\begin{array}{l}\text { masalah tentang } \\
\text { negasi pernyataan } \\
\text { berkuantor.. }\end{array}$ \\
\hline & $\begin{array}{l}\text { Kesulitan } \\
\text { membuktikan } \\
\text { kebenaran suatu } \\
\text { pernyataan } \\
\text { berkuantor }\end{array}$ & $\begin{array}{l}\text { Sudah bisa } \\
\text { membuktikan } \\
\text { kebenaran suatu } \\
\text { pernyataan } \\
\text { berkuantor. }\end{array}$ \\
\hline \multirow[t]{2}{*}{$\mathrm{C}$} & $\begin{array}{l}\text { Belum tepat } \\
\text { mengilustrasikan } \\
\text { nilai kebenaran } \\
\text { dan negasi } \\
\text { kemudian siswa B } \\
\text { membantu } \\
\text { mengilustrasikan } \\
\text { dengan tepat di } \\
\text { depan kelas. }\end{array}$ & $\begin{array}{l}\text { Sudah bisa } \\
\text { mengilustrasikan } \\
\text { untuk pernyataan } \\
\text { hipotesis yang } \\
\text { lain. }\end{array}$ \\
\hline & $\begin{array}{l}\text { Belum tepat } \\
\text { mengilustrasikan } \\
\text { aktivitas } 2 \text {. }\end{array}$ & $\begin{array}{l}\text { Sudah bisa } \\
\text { mengilustrasikan } \\
\text { untuk aktivitas } \\
\text { yang lain. }\end{array}$ \\
\hline
\end{tabular}

\section{5) Revisi II}

Revisi II dilakukan berdasarkan hasil uji coba kelompok kecil. Beberapa hal yang direvisi antara lain

a) Kalimat perintah yang tidak dipahami siswa diperjelas sehingga waktu bisa efektif.

b) Menyelipkan beberapa pertanyaan dan ilustrasi agar materi prasyarat bisa dipahami dengan cepat.

c) Perbaikan ilustrasi gambar dan warna.

6) Distribusi Produk Akhir

Proses cetak di percetakan.

\section{B. Pembahasan}

Proses pengembangan dalam penelitian ini telah menghasilkan produk berupa bahan ajar matematika berbasis integrasi-interkoneksi dan kontekstual untuk siswa SMA/MA. Bahan ajar ini dikembangkan sesuai dengan tujuannya adalah untuk memfasilitasi kemampuan penalaran dan pemecahan masalah siswa, serta mengetahui dampak penggunaan bahan ajar tersebut. Dalam usaha pencapaian tujuan tersebut, metode yang sesuai dengan penelitian ini adalah metode penelitian pengembangan model Borg \& Gall dengan tiga tahap yaitu tahap pendahuluan, tahap pengembangan, dan tahap validasi. 
Pengembangan Bahan Ajar Matematika Berbasis Integrasi-Interkoneksi untuk Memfasilitasi

Kemampuan Penalaran dan Pemecahan Masalah Siswa

Mulin Nu'man

Hasil analisis karakteristik siswa diketahui bahwa siswa belum dapat memahami materi matematika dengan baik sehingga berakibat pada hasil belajar yang dicapai masih rendah.Selain itu, siswa pasif ketika pembelajaran berlangsung, hal ini terlihat ketika guru memberikan kesempatan untuk bertanya namun tidak ada yang bertanya.Selanjutnya siswa menyukai kegiatan diskusi dengan temannya namun guru belum memfasilitasinya. Kemudian dijumpai bahwa siswa cenderung ramai pada 2 jam terakhir pembelajaran.

Pada tahap uji coba, pembelajaran dilakukan secara berkelompok dengan metode guided inquiry tujuannya agar siswa dapat berdiskusi dengan temannya dan lebih aktif ketika di kelas, selain itu bertujuan agar guru lebih mudah memantau keadaan kelas sehingga memudahkan ketika memberi bimbingan. Hal tersebut sesuai dengan pendapat Ibrahim dan Suparni (2008: 108) bahwa kelebihan dengan berdiskusi adalah siswa lebih aktif dalam pembelajaran serta siswa dapat berlatih mengemukakan pendapat di depan umum dan menghargai pendapat orang lain. Selanjutnya dengan berkelompok secara tidak langsung dapat menumbuhkan sikap saling tolong di antara siswa dimana siswa yang sudah paham dapat membantu siswa yang belum paham karena terkadang dijumpai ada siswa yang malu bertanya kepada guru dan lebih senang bertanya kepada temannya.

Berdasarkan hasil pengamatan observer diperoleh respon-respon siswa, respon-respon tersebut ada yang sesuai dengan dugaan yang terdapat dalam HLT serta ada juga respon diluar dugaan HLT yang telah disusun. Setelah dilaksanakan tahap uji coba, bahan ajar mengalami beberapa perbaikan.Selain bahan ajar, rencana pelaksanaan pembelajaran (RPP) maupun HLT juga mengalami beberapa perbaikan.Sejauh ini hasil penelitian menunjukkan bahwa bahan ajar matematika berhasil dikembangkan.

Kevalidan bahan ajar ditunjukkan oleh penilaian validator bahan ajar yang mengatakan bahwa bahan ajar masuk kategori sangat baik dari segi isi, penyajian, maupun bahasa. Adapun skor rata-rata total penilaian bahan ajar dari validator adalah 157,5 atau masuk dalam kategori sangat baik.

Peningkatan yang terjadi dalam
pembelajaran/dampak prosesnya, peneliti yang bertindak sebagai guru menetapkan tiga siswa untuk dijadikan subjek penelitian khusus, hal ini dilakukan agar peningkatan yang terjadi lebih mudah untuk diamati.Ketiga siswa yang diamati secara khusus diberi label siswa A, B, dan C. Hasil pengamatan guru dituangkan dalam hasil penelitian dan didukung oleh pengamatan observer.Berdasarkan pengamatan guru, ketiga siswa mengalami peningkatan yaitu peningkatan respon dari stimulus yang diberikan, seperti lebih aktif bertanya.Selain itu siswa lebih percaya diri ketika mengungkapkan suatu pernyataan.Ketiga siswa telah mengalami progres dari yang sebelumnya belum tepat ketika mengerjakan sesuatu hingga tepat ketika mengerjakan sesuatu.Lebih rinci terkait hal ini bisa dilihat kembali pada bagian analisis data pembelajaran.Pernyataan tersebut secara tidak langsung dapat menjawab permasalahan terkait siswa yang cenderung pasif di kelas. Hal tersebut sejalan dengan pendapat Gusti Ayu Suarsani (2011: 54) bahwa metode guided inquiry dapat menambah kepercayaan diri siswa dan membangkitkan motivasi siswa untuk belajar lebih giat.

Kepraktisan bahan ajar terlihat dari respon siswa yang diperoleh dari angket respon siswa.Angket respon yang dibagikan kepada siswa terdiri dari 19 butir pernyataan terkait dengan pembelajaran dengan menggunakan bahan ajar yaitu 10 butir pernyataan positif dan 9 butir pernyataan negatif.

Efektitifas bahan ajar dilihat dari hasil postets. Hasil posttest menunjukkan bahwa ratarata kemampuan penalaran matematis siswa adalah 77,21 dan rata-rata kemampuan pemecahan masalah siswa adalah 76.01.

Penelitian yang dilakukan tidak serta merta dapat berjalan sesuai dengan apa yang direncanakan. Ada beberapa hal yang menjadi keterbatasan dalam penelitian ini antara lain alokasi waktu yang direncanakan sebelumnya mengalami penyempitan sehingga waktu belajar sedikit berkurang, hal ini menyebabkan ada beberapa materi yang terkesan dikebut dalam pengajarannya. Masalah alokasi waktu ini sejalan dengan pendapat Prambudi (2010: 43) bahwa salah satu kelemahan metode guided inquiry adalah terkadang dalam meng- 
implementasikannya memerlukan waktu yang panjang sehingga guru sering kesulitan menyesuaikan dengan waktu yang telah ditentukan.

\section{PENUTUP}

\section{A. Kesimpulan}

Berdasarkan hasil penelitian dan pembahasan yang telah dipaparkan sebelumnya, dapat diambil keimpulan sebagai berikut:

1. Bahan ajar matematika integratifinterkonektif berbasis kontekstual dilakukan dengan model pengembangan Borg \& Gallyang meliputi tahap pendahuluan, tahap pengembangan, dan tahap validasi. Bahan ajar matematika integratif-interkonektif berbasis kontekstual yang kembangkan mendapat penilaian sangat baik dari penilai dengan skor rata-rata 157,5 dari skor maksimal 172 atau dengan persentase $91,2 \%$, ratarata kemampuan penalaran matematis 77,21 dan rata-rata kemampuan pemecahan masalah 76,01 .

2. Dampak penggunaan bahan ajar matematika integratif-interkonektif berbasis kontekstual pada materi logika matematika antara lain siswa lebih aktif dan antusias dalam kegiatan pembelajaran jika ditinjau dari segi prosesnya.

\section{DAFTAR PUSTAKA}

BSNP. 2006. Panduan Penyusunan Kurikulum Tingkat Satuan Pendidikan Jenjang Pendidikan Dasar dan Menengah. Jakarta: Depdiknas.

Hendriana, Heris \& Soemarmo, Utari. 2014. Penilaian Pembelajaran Matematika. Bandung: PT Refika Aditama

Ibrahim \& Suparni. 2008. Strategi Pembelajaran Matematika. Yogyakarta: Sukses Offset.

Komalasari, Kokom. 2010. Pembelajaran Kontekstual dan Aplikasi. Bandung: Refika Aditama.

http://litbang.kemdikbud.go.id/index.php/timss (1999-2007) http://litbang.kemdikbud.go.id/index.php/survei -internasional-pisa (2000-2006)

MENDIKNAS. 2008. Panduan Pengembangan Bahan Ajar. Jakarta: Depdiknas.

Mussafi. 2014. Hand Out Islam dan Sains. Yogyakarta: UIN Sunan Kalijaga

https://www.oecd.org/pisa/pisaproducts/466197 03.pdf (2009)

https://www.oecd.org/pisa/keyfindings/pisa2012-results-overview.pdf (2012)

Prambudi, S. 2010. Strategi Pembelajaran Inkuiri. Dikutip dari http://shoimprambudi.wordpress.com/2010/ 10/18/strategi-pembelajaran-inkuiri/ tanggal 20 Mei 2016.

Ramadhan, Danny, Wasis. 2013. Analisis Perbandingan Level Kognitif dan keterampilan Proses Sains dalam Standar Isi (SI), Soal Ujian Nasional (UN), Soal Trends in International Mathematics and Science Study (TIMMS), dan Soal Programme for International Student Assessment (PISA). Jurnal Inovasi Pendidikan Fisika, Vol 02 No 01 Tahun 2013.

Riyanto, Bambang dan Rusdy A. Siroj. Meningkatkan Kemampuan Penalaran dan Prestasi Matematika dengan Pendekatan Konstruktivisme Pada Siswa Sekolah Menengah atas. JURNAL PENDIDIKAN MATEMATIKA, VOLUME 5. NO. 2 JULI 2011

Shadiq, Fajar. 2004. Pemecahan Masalah, Penalaran, dan Komunikasi. Disampaikan pada Diklat Instruktur/Pengembang Matematika SMA Jenjang Dasar Tanggal 6 sampai 19 Agustus 2004 di PPPG Matematika.

Suarsani, Gusti Ayu. 2011. Pengaruh Model Pembelajaran Inkuiri Terbimbing terhadap Hasil Belajar Kimia Siswa Kelas XI IPA SMA PGRI Gianyar 3 Ubud. Tesis tidak diterbitkan, Singaraja. Undiska.

Sugiyono. 2010. Metode Penelitian Kuantitatif, Kualitatif, dan $R \& D$. Bandung: Alfabeta. 
Pengembangan Bahan Ajar Matematika Berbasis Integrasi-Interkoneksi untuk Memfasilitasi Kemampuan Penalaran dan Pemecahan Masalah Siswa Mulin Nu'man

Suryadi, Ace. 2014. Pendidikan Indonesia Menuju 2025. Bandung:PT Remaja Rosdakarya.

http://timssandpirls.bc.edu/data-release-

2011/pdf/Overview-TIMSS-and-PIRLS-

2011-Achievement.pdf (2011)

Wardhani, Sri, dan Rumiati. 2011. Instrumen Penilaian Hasil Belajar Matematika SMP: Belajar dari TIMSS dan PISA. Yogyakarta: PPPPTK. 